\title{
Angles
}

New Perspectives on the Anglophone World

$10 \mid 2020$

Creating the Enemy

\section{The Hollywood Indian Stereotype: The Cinematic Othering and Assimilation of Native Americans at the Turn of the $20^{\text {th }}$ Century}

Martin Berny

\section{(2) OpenEdition}

Journals

Electronic version

URL: http://journals.openedition.org/angles/331

DOI: 10.4000/angles.331

ISSN: 2274-2042

Publisher

Société des Anglicistes de l'Enseignement Supérieur

\section{Electronic reference}

Martin Berny, «The Hollywood Indian Stereotype: The Cinematic Othering and Assimilation of Native Americans at the Turn of the 20 th Century », Angles [Online], $10 \mid 2020$, Online since 01 April 2020, connection on 21 December 2020. URL : http://journals.openedition.org/angles/331 ; DOI : https:// doi.org/10.4000/angles.331

This text was automatically generated on 21 December 2020 .

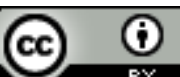

Angles est mise à disposition selon les termes de la Licence Creative Commons Attribution 4.0 International. 


\title{
The Hollywood Indian Stereotype: The Cinematic Othering and Assimilation of Native Americans at the Turn of the $20^{\text {th }}$ Century
}

\author{
Martin Berny
}

\section{The Elaboration of a Double Stereotype}

1 The representation of Native Americans in popular culture is to this day a matter of deep puzzlement. Images spread through literary works such as James Fenimore Cooper's Leatherstocking Tales, the paintings of Frederic Remington - whose influence on John Ford's Westerns should not be undervalued -, or mainstream Hollywood compose a contradictory profile. A binary depiction of the Native characters maintained itself through the emergence of the Western as a film genre: the more positive noble Indian and the bloodthirsty savage. ${ }^{1}$ This cleavage demonstrates the preconceived attitude of the norm towards the Natives - an attitude that shaped Hollywood and that the film industry eventually reinforced and supplemented. As D.H. Lawrence wrote in the New York Times in a 1924 article, "it is almost impossible for the white people to approach the Indian without either sentimentality or dislike" (Lawrence 1927).

2 This double stereotype deployed through American cinema and literature fits the everevolving curve that defines the limits of a cohesive norm and the dominant vision of what the country is, of what it means to be American. Standing Bear (1978), the Ponca Native American chief, argued that "the white man does not understand the Indian for the reason that he does not understand America". In this perspective, the Indian looking glass magnifies America's lack of self-knowledge. In correlation with the closing of the frontier and the settling of the West, a certain form of nostalgia prevailed. The mythologizing of the West led to the opening of a new imaginary space 
that Americans could fill with their fantasies about the Natives and the land they appropriated for themselves. This tradition gave birth to the Hollywood Indian, a "cinematic creation springing directly from the ubiquitous images of the old blood thirsty savage and his alter ego, the noble savage" (Kilpatrick 1999: 15).

3 Heroic Indian figures could be found in dime novels, short and direct stories popularized from their first publication in 1860 to their survival through the cinematographic medium. Buffalo Bill's Wild West Show also contributed to the everlasting pairing of cowboys and Indians as a unit. Although the show included real cowboys and Indians, it led to a profound misrepresentation of the Natives. Even though Cody's intent was to give more authenticity to the performances, enlisting known leaders such as Sitting Bull or Crazy Horse, and giving them a better treatment than what reservation life could offer, Wild West Show remained an act - and a constricted one at that - that most of the public processed as real. ${ }^{2}$ Native performers would either play the defeated enemy or, with Sitting Bull and other Indian leaders, a more dignified and romanticized Indian figure. ${ }^{3}$ The technological evolution of the times is tied to this particular fantasized Indian. Thomas Edison Company's Kinetoscope features such as Sioux Ghost Dance (1894) and the coverage of Cody's show, Parade of Buffalo Bill's Wild West Show (1898), had a profound and powerful ideological and sociological impact - although it is worth observing that Kinetoscope features could only be seen by one individual at a time, privately through a peephole. ${ }^{4}$ Cody's later feature, The Indian War Refought (1914) - which had as alternate title The Wars for Civilization in America -, enacted under the direction of the War Department and approved by the United States government, had a much broader influence. Deemed as "the most realistic film of the age", its "great historical and educational value" was used in ads as a forceful marketing argument (Figure 1). "Of more than ordinary interest to the public", the film became the official record of the Battle of Wounded Knee, glorifying the massacre of hundreds of Indians, mostly women and children, as an act of heroism. 
Figure 1. Ad printed in The Moving Picture World claiming The Indian Wars was "historically correct"

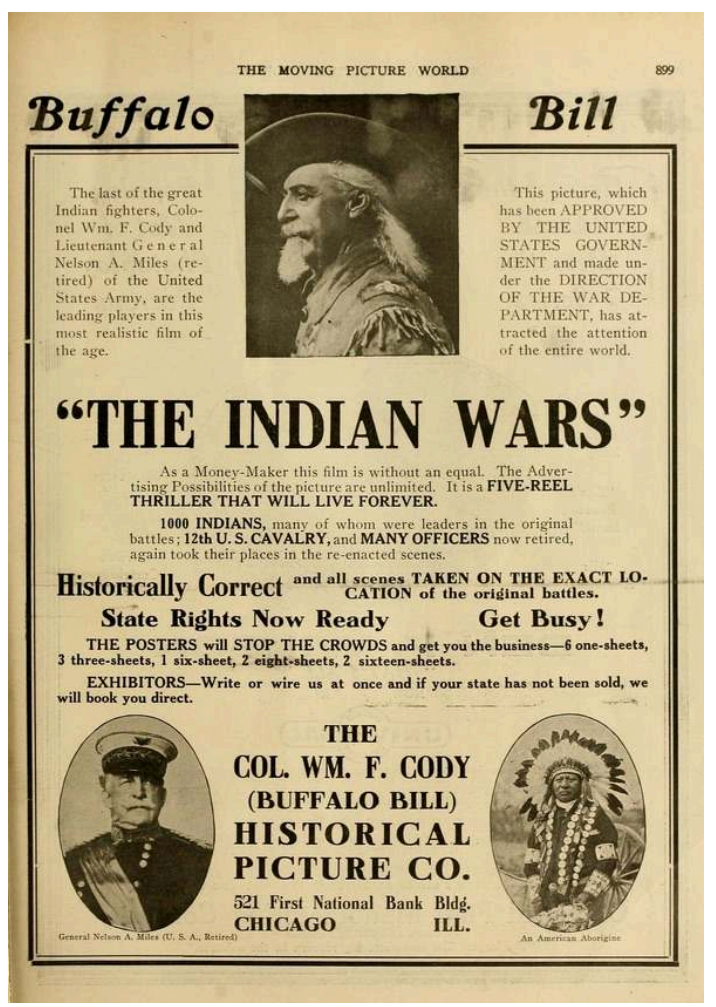

Source: The Moving Picture World 21.7 (15 August 1914): 899 (online)

4 More surprisingly, some movies from the early $20^{\text {th }}$ century may be considered as quite progressive with a considerate, if not entirely accurate, depiction of the Indians. The general belief of the era was that Native Americans were about to disappear and that the opportunity to collect information about their way of life would be lost. ${ }^{5}$ Their impending extinction partially explains the sympathetic description ${ }^{6}$ in motion pictures such as The Red Man and the Child (1908), D.W. Griffith's first Western, The Indian Runner's Romance (1909), and The Red Man's View ${ }^{7}$ (1909). Interesting films were produced at the time in this humanistic perspective, attempting to present the Indians' point of view - Winnebago director James Young Deer even directed the first Native American film, White Fawn's Devotion as early as in 1910 -, but their anthropological dimension was not fully considered until much later. In The Land of the Head Hunters (1914), directed by photographer and ethnologist Edward S. Curtis a man who committed most of his life to the production of a book series entitled The North American Indian, published between 1907 and 1930 - provided a substantial documentation of traditional Native American life and culture but was originally accused of being overly romantic and not scientific enough. ${ }^{8}$

Curtis' photogravures do lean on the artistic side, their lighting and composition are too well adjusted to recreate the feel of the real. Yet they also bear testimony to his relationship with his subjects, his closeness and true understanding of the many tribes he put on record in the making of his work. His film shares the same complexity, being both historically and culturally accurate and melodramatic in its narrative imperatives. Expertly staged, In the Land of the Head Hunters showcases traditional performances of the mask dances and depicts scenes of daily life in a naturalistic manner (Figure 2), allowing the Natives to reinvent their own past, while the artificial plot stems from a 
prophetic vision and involves witchcraft and sorcerers to substantiate the main character's spiritual quest.

Figure 2. Stills depicting scenes from Indian daily life and traditional performances from In the Land of the Head Hunters (1914), dir. Edward S. Curtis

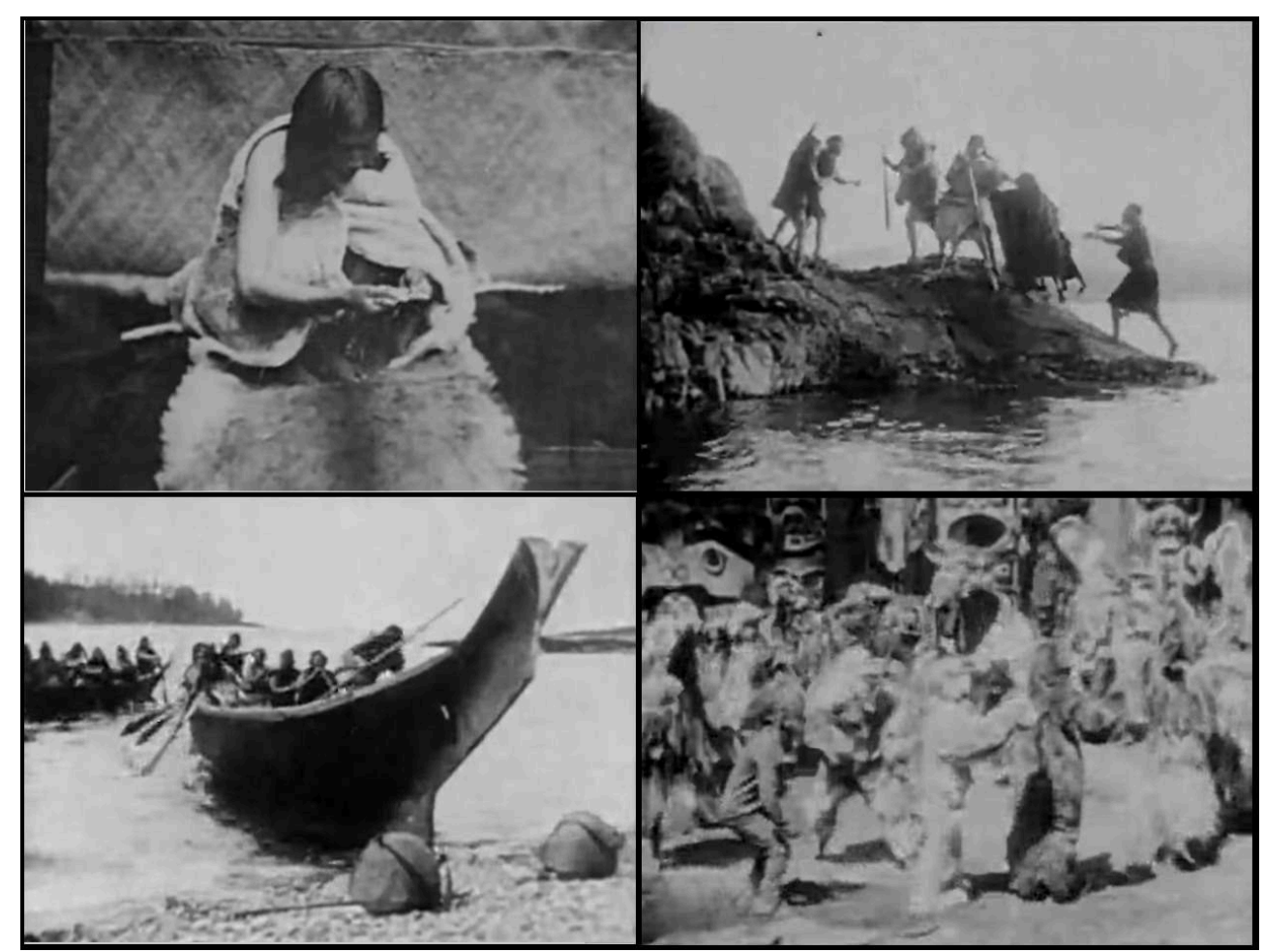

Source: https://en.wikipedia.org/wiki/File:In_the_Land_of_the_Head_Hunters_(1914).webm

With the help of producer-manager George Hunt, whose extensive knowledge of Native culture was instrumental in gathering masks, ceremonial artifacts and in the making of the sets, Curtis made objects that could only have been seen in a museum or imagined through a textbook description become alive on the screen. The "salvage paradigm" in ethnography, as well as Franz Boas's extended work on the Kawkiutl people, was in the spirit of the times, and cinema was a new medium of choice to document the practices of a vanishing race.

7 Stephen W. Bush, who complained in an earlier article of the lack of "real Indians" on celluloid (Bush 1911), wrote in his review of the film that the Indian mind was "constitutionally incapable of acting", suggesting that Curtis had "great power" over his cast (Bush 1914). For Bush, the film was paradoxically a "study in ethnology" conceived as "an epic", "strangely reminiscent of 'Parsifal' and 'the Ring of Nibelungs [sic]"'. It surely borrows elements from the operatic genre, noticeably in terms of structure, as the plot recycles the old three-act pattern: attack, revenge, and rescue; and the love affair between Motana (Stanley Hunt) and Naida (Sarah Constance Smith Hunt), the sensational capture of the whale, the hunting of the sea-lions, appear as a pretext or narrative connecting segments to showcase dances with a vividness that overshadows the mise-en-scène and bears the marks of modernity.

Neither a straightforward documentary ${ }^{9}$ nor entirely fictional, the film epitomizes the essential question of recording reality which filmmaking pioneers had to face in the early days of the film industry. It also provides its share of escapism - entertainment is 
never far. Curtis' desire to portray prohibited rituals, which in itself could be seen as an act of resistance, also serves a logic of preservation. This approach stands midway between the objective scientific agenda that involves the ethnologist and the Natives as subjects, and the more or less conscious addition of a third party, a prospective white audience solicited through the exoticism of the plot. While it was the first featurelength film to exclusively show Native Americans and was the product of a true collaboration between Curtis and the Kwakwaka'wakw (or Kwakiutl) people, In the Land of the Head Hunters brings to the fore the problem of representation and its aim to forge a public imaginary or to elicit a collective reaction from the audience - whose interest does it serve?

9 Although the film was a financial catastrophe, it earned great reviews after its premiere at New York's Casino Theatre in late autumn 1914. According to George I. Quimby, the professor of anthropology who completed, with Bill Holm, a restored version of the film "adding a soundtrack in the Kwakiutl language" in $1974^{10}$ (Quimby 1990: 53), the film's box office disaster was due to World Film Company's failure to promote it; Quimby further asserts that it "had no chance of financial success in the 1914-15 market for war and propaganda motion pictures" (53).

In 1912, D. W. Griffith directed two movies produced through the Biograph Company, A Pueblo Legend (featuring Mary Pickford) and The Massacre - the latter would not be released until 1914 in the U.S. While A Pueblo Legend thrives on the same variety of romanticism and mysticism as In The Land of the Head Hunters - the main character is again an Indian sent on a quest revolving around Native mythology - The Massacre is based on the character of infamous Lt. Col. Custer. It stages a brutal and unwarranted surprise attack on an Indian village that eventually leads to an equally violent act of retaliation. The editing process allows Griffith to show both sides of the incident with a mirroring effect - the wife and baby of a white settler are shown as well as their counterparts within the tribe. The back and forth in editing between the two sides could have allowed for a shared empathy towards the victims of the West, but Griffith somehow does not maintain the balanced approach.

11 The Indian mother's death is not seen; while attempting to escape the scene of the attack, she is shot and collapses and disappears at the lower limit of the frame of a rather long shot; on the other hand, there is a full emotional setup showing the perils incurred by the whites. The distress of the white woman and her baby is shown through a recurrent and much closer shot (Figure 3). A priest and a gambler are caught amidst the firing, hanging on to each other in a last moment of shared humanity. Both men are shot and die holding on to the objects that characterize them: a Bible for the priest and an ace of spades for the gambler. It is almost as if they were clinging to the frame itself, maintaining their last gasp as long as possible, proving that, contrary to the Native woman previously erased and evacuated from the frame, their death is of a much greater importance. Melodrama is absent when depicting the victimization of Indians, relegated to the status of plot device, while a wider latitude is given to cinematically express the anguish of the settlers. Finally, the cavalry charges and saves the settler's family - the murdered Natives are long forgotten and so is the initial motivation for their attack. 
Figure 3. Stills from D.W. Griffith, The Massacre (1912), comparing the treatment of two women holding babies, one Indian (left), the other white (right)

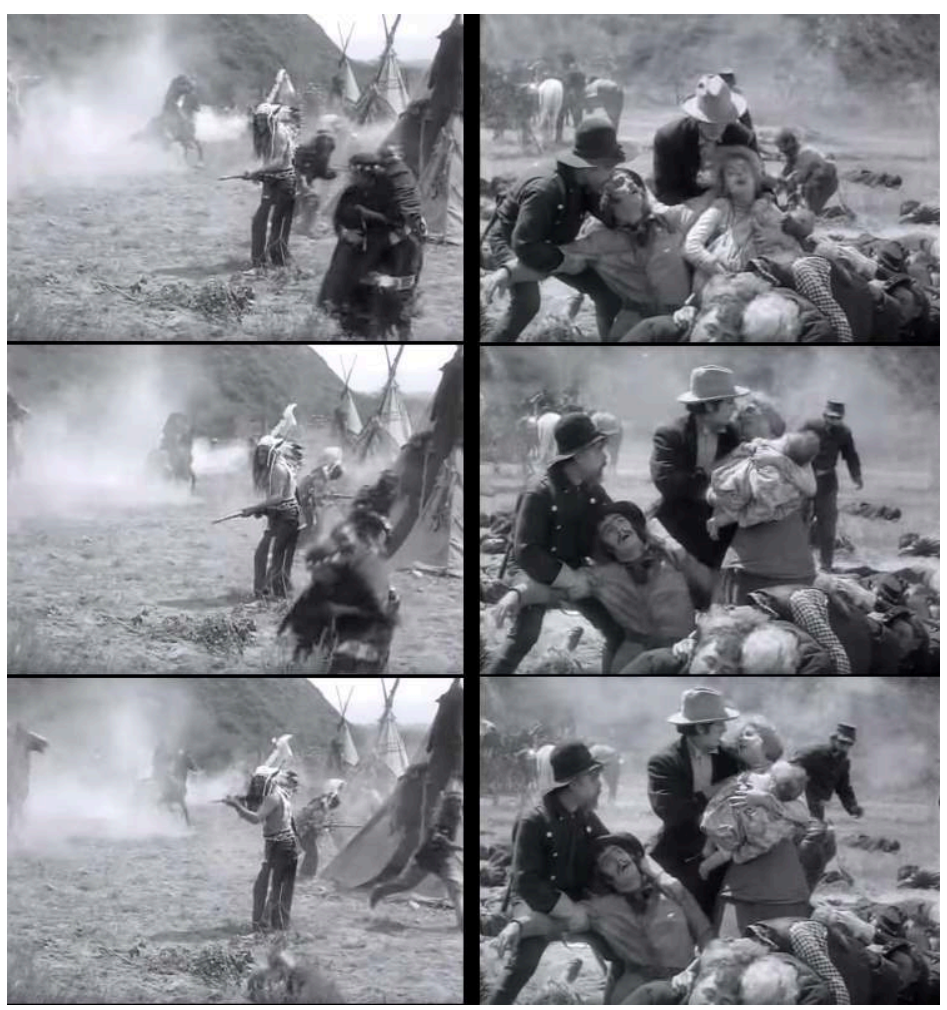

Source: https://www.youtube.com/watch?v=h5rSAJ9Fw7I their own acts of violence. It seems that while Griffith had all the elements to build a morally balanced narrative, it was impossible to get to the more humane and fully developed conclusion. Instead of affirming that violence begets violence, The Massacre highlights the discrepancies between Whites and Indians in terms of representation and prefigures Griffith's turn to a more racist ideology with his infamous Birth of a Nation (1915) (on Griffith, see Jay 2000).

This demonstrates the radicalization of the dominant thought. In the Hollywood realm, the noble Indian belongs to a pre-colonial past, before Europeans set foot on the Continent; it is therefore an object of displaced nostalgia. This figure reflects the primitive wilderness that has receded and has no relevance in a world concerned with the progress of civilization. Putting temporal distance between the Natives and the modern world segregates them from the collective whole and spatially asserts the moderns' rightful possession of the land. As Stam and Shoat explain, "the elimination of the Indian allows for elegiac nostalgia as a way to treat Indians only in the past tense and thus dismiss their claims in the present" (Stam \& Shoat 1994: 118). This is also true of someone as intimate with the Indians as Edward S. Curtis, whose approach "often led him to suppress evidence of the contemporary lives of the Indians that he photographed, in effect freezing his Native American subjects in a timeless past" (Jentz 2018: 128). There is something detrimental at play here, a "thanatological tenderness" (Stam \& Shoat 1994: 118) which should not be overlooked, as it establishes the complex nature of the double stereotype. In Griffith's case, romanticizing the Natives was a step 
forward to making the antagonist out of them. In other words, "the savages' nobility does not contradict their primitiveness but confirms it" (Jay 2000: 11).

The advent of modernity contributed to the demise of the good Indian stereotype. When the context changed to the threatening climate of World War I in Europe, even though the United States strived to maintain its neutrality until 1917, the motion picture production crystalized more closely on the savage archetype, a more clearly shaped antagonist that could arouse and project the national feeling into the menacing contemporary scene. It also laid the ground for the war economy that supported America's claim to global dominance in the $20^{\text {th }}$ century.

\section{From Cultural Mimesis to Cultural Nemesis}

Adorno's and Horkheimer's concept of the culture industry (Kulturindustrie), initially presented in a section of their Dialectic of Enlightenment (1947), is helpful to grasp the interests of such an enterprise. They argue elements such as stereotypes and images manufactured by Hollywood have a remarkable and dangerous impact on the whole social process. Entertainment is a most serious business, which serves a definite political agenda. The toxicity and perils of mass culture and its effects on the evolution of society is all the more perceptible within a genre as popular as the Western. This particular enemy image, like any popular content, was manufactured in a way that "reflected the interests of the producers and the exigencies of the market, both of which demanded the domination and manipulation of mass consciousness" (Widkin 2003). No one could escape this undifferentiated representation of the Natives. It impregnated more or less actively moviegoers' psyche to the extent that we are still unable to 'unsee' it or to form a reply and challenge its homogeneity.

16 I would argue that while part of an organic process of defense and structuration of American society and its overall collective consciousness, this mechanism implemented, controlled, and amplified a not-so-conscious desire for a genuine national moment. While the industry serves the function of social integration, it is hard to calculate the degree of responsibility of the audience itself in the making of such a process. Siegfried Kracauer explains films reflect a nation's mentality because they "are never the product of an individual" and appeal "to the anonymous multitude" (Kracauer 1966: 5). He adds, "American audiences receive what Hollywood wants them to want; but in the long run public desires determine the nature of Hollywood films" (6). Adjusting to what might be a not so passive but movable spectator, the industry knowingly triggers "outward projections of inner urges" (8). However, these urges work on the collective and unconscious level.

17 If we were to deconstruct this clever and powerful machinery, René Girard's scapegoat mechanism would allow for us to see plainly the different parties involved. The French philosopher posits throughout his work, including Violence and the Sacred (1972) and The Scapegoat (1982), that culture is based on imitation, the ancient notion of mimesis. Motion pictures are, due to the large scale at which they operate, powerful learning tools from which we learn how to replicate our roles within society. According to Girard, this cultural phenomenon is built upon a desire that is mediated by the figure of the Other and goes through four stages: mimetic desire, mimetic rivalry, mimetic crisis and a final scapegoat resolution. In the case of internal mediation - that is to say when the subject and his model inhabit the same world - rivalry emerges and produces a 
crisis of undifferentiation. To save itself from self-destruction, the community needs to focus on an enemy image or scapegoat that must be sacrificed in a self-asserting act.

Because imitation implies competition, it is convincing to approach the relationship between white settlers and Native Americans, as well as America's History in a broader sense, as an interpersonal desire for a national moment. This rivalry, consisting in the claim of being the authentic and ultimate American, would make the land and the country itself the object of desire. Imitation could also indicate the settlers' underlying fear of discovering that the criteria of differentiation between the two of them are quite effaceable. In that sense, mimetic conflict would make of these rivals and antagonists actual doubles - something attested by Buffalo Bill's Wild West Show, reenacted by children playing cowboys and Indians. The assimilation of Indians, as a reverse mimetic effect, would ultimately generate a fear of contamination, that is to say the fear of coming to realize that you are unconsciously mimicking your enemy. Because the Natives were the model to mimic to survive and adapt to the wilderness Turner's own words remind us that the colonist must follow the Indian trails (Turner 1920: 14) - they became the enemy and the obstacle to white civilization or Americanization. The double nature of this complex phenomenon of imitation and differentiation empowers the fabrication of the enemy image, and shows how a twophase process would eventually lead to the erasure of the good Indian stereotype.

This mechanism is even more striking at a global scale. When facing disintegration, the community needs to rebuild a form of unity through a violence of all against one scapegoat. Here, the death of the Indian would be necessary for the survival of the whole nation. Girard insists on the fact that "in order to exist as a social reality [...] scapegoating must remain nonconscious", that "the operation of transferring sins from community to victim seemed to occur from beyond, without their own real participation" (Girard 2001: 155). Is that to say that audiences were unaware of the building of this enemy image? The fragmentation of society in the early $20^{\text {th }}$ century and the worldwide tensions of the 1910s surely oriented the focus on the most alien and marginal figure. But how could we not yet be conscious that reconciling the community through this enemy image, at the expense of the Natives, was also a way of somehow legalizing or sanctifying their collective murder and its duplication through the cinematic medium? The emergence of the Western genre made unnecessary to retrospectively look back upon the genocide and the assimilation of Indians, preventing any attempt at a communal self-analysis.

Girard goes even further, suggesting that the ritualization of the sacrifice and substitution of a victim for another is "the first symbolic sign ever invented" by the hominids prior to representation and language (Girard 2008: 107). That would make the Hollywood Indian and its systematic extermination on screen the very basis of the Western narrative, and not its mere by-product. This ethnologic thesis is reminiscent of the challenged notion of collective murder as the origin of culture in Freud's controversial Totem and Taboo (1913). Expanding on Girard's view, we could consider the ritual sacrifice of the Indian in motion pictures as a psychological imperative to defuse actual violence, or to deal with guilt and reconciliation within the margins of mainstream society. ${ }^{11}$

21 I rely on Philip Cushman's concept of the 'empty self' to further explain the implication of such a process of passive and unconscious reception of the enemy image on the part of the audience. In Constructing the Self, Constructing America, Cushman states that "both 
capitalism and racism can be understood in part as aspects of a fledging immigrant nation searching for its identity - that is, as part of a people's attempt to configure the self - in a time of rapid and disorienting sociohistorical change" (Cushman 1996: 36). That seems especially true for the period spanning from the settling of the frontier to the two World Wars. Cushman establishes that it was then much easier for mainstream white America to define this self through what it was not, but reminds us that it was not only convenient to alienate the Natives: such a self and a specific constructed reality are configured by those in power.

An underlying current of radicalization rose in the 1910s that slowly contributed to embrace the war effort and the pursuit of an efficient capitalistic economy that heavily relied on combat. In the U.S., the standardization of mass culture may have begun with this particular Indian stereotype. The more fragmented and atomized the individual had become, the more focused, all-encompassing and over-simplified the enemy image turned out to be. What might not have been suspected was that something was lost in the process leading to a hegemonic American self-image. Everything that was at first mimicked from the Indian figure - a fruitful relation to Nature, a non-nuclear family structure, mutualism between races - was then rejected and projected unto a negative stereotype. This form of schizophrenia was induced by a capitalist discourse of interrelation that makes it virtually impossible to dissociate consumerism and individualism from warfare and racism.

\section{The Vanishing American (1925)}

Originally published as a serial in Ladies Home Journal in 1922-1923, the screenplay of The Vanishing American penned by Zane Grey carried a warning message about the responsibility of the government in the Natives' suffering that was ultimately toned down by Paramount. The movie directed by George B. Seitz remained sympathetic to the Indians in spite of the fact that the missionaries and the corrupted agent of the Indian affairs were more lightly portrayed than planned initially. The Vanishing American offers a unique perspective on the interconnectedness between the war effort and the assimilation or disintegration of Indian identity. It retrospectively explores the same time period as Curtis or Griffith and takes place before the unexpected demographic jump of the 1930s.

Grey's use of a color metaphor in his story conveys the implication of the process of assimilation. When the main character, an Indian man named Nophaie, dies, the very moment of his passing is described through a skin color change - Nophaie turns white: "his eyes were those of an Indian, but his face seemed that of a white man" (Kilpatrick 1999: 30-1). Death for the Indians means becoming white; the melting of Native people into white mainstream society, their very extinction (Figure 4). 


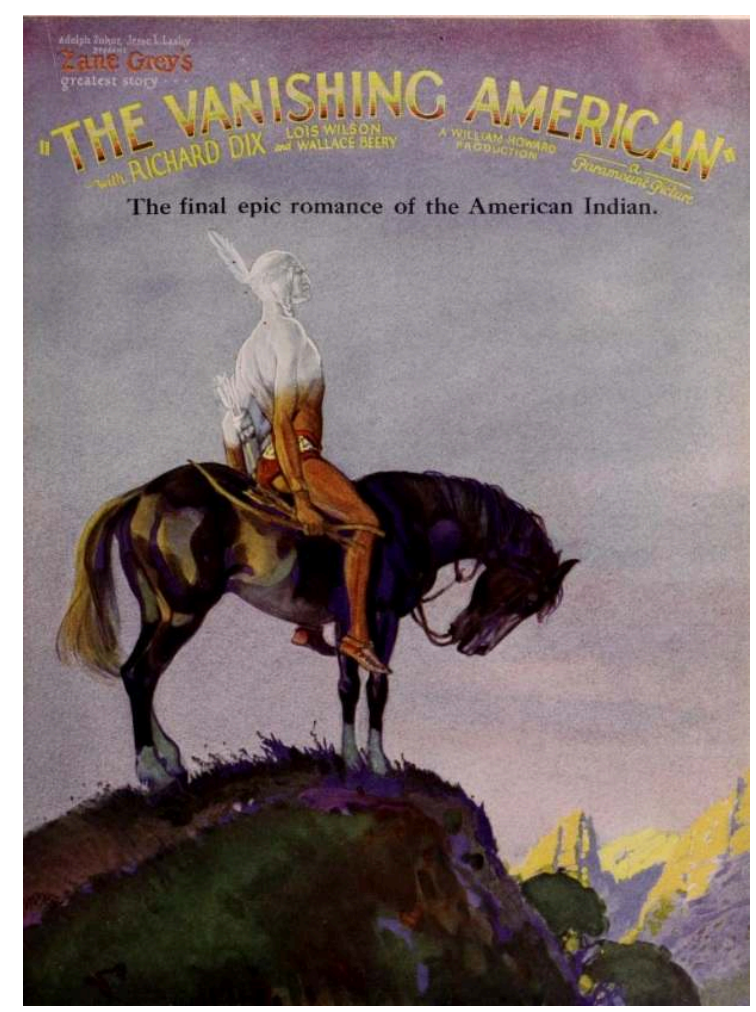

Source: IMDB

The possibility of interracial marriage and the fear of miscegenation are pervasive themes as the narrative unfolds. Nophaie's bond with Marion (or Marian), the white teacher at the Native American School, ends with Nophaie's death, thus depriving the story of its full progressive development. Implicitly, it seems death is the price to pay for an interracial relationship.

As an inversion of James Fenimore Cooper's Natty Bumppo becoming a better Indian than the actual Indians, Nophaie (Richard Dix) dies as a white man - a not so subtle translation from Zane Grey's metaphor of turning white into the cinematic medium. His own people kill him when he tries to stop an ongoing and devastating battle, his arms outstretched as a Christ-figure, sacrificing himself to appease the tensions between the two races. The bullet that wounds him went through a copy of the New Testament, enlightening a sentence from the Gospel According to Matthew (10:39) that had always puzzled Nophaie and that Marion (Lois Wilson) had not been able to make clear: "he that findeth his life shall lose it; and he that loseth his life for my sake, shall find it." The verse confirms there is no place to inhabit for the Natives in the temporal world, but only in the hereafter, or in the proto-history of Western mythology.

His last "true" words as a dying man are those of a true revelation. Although "it grows dark" - as opposed to turning white - he is able to see his people through a veil; a particular word that echoes the invisibility and impending vanishing of his entire race. Just like Cooper's Chingachgook and Uncas were positive portrayals of the Indians, Nophaie is the last of his kind, a "proto-American", designed to disappear. Cooper's stories bear the mark of a form of biased Darwinism, more or less implicitly racist, the Whites being physically and mentally superior to the Natives. The motif of the "White Indian" - in the case of The Last of the Mohicans (1826), Natty Bumppo - becoming a 
better Indian than the Natives was to re-emerge throughout film history, the most recent and remarkable occurrence being, in spite of the good intentions of the director, Kevin Costner's Dances With Wolves (1990). Just as Frederic Jackson Turner's theory of the frontier - an idea that asserts this "meeting point between savagery and civilization" and westward expansion led to the "Americanization" of the colonists (Turner 1921: 3) - served the larger purpose of building a nationalistic mythology at the turn of the $20^{\text {th }}$ century, Cooper's novels and Seitz's Vanishing American present a common way of seizing the Natives as a justification for the actual dominion of mainstream society.

Mortally wounded, Nophaie makes it just in time for redemption, dying as a Christian martyr. The Native has merged into the conforming frame of the master race, accepting his death as the sign of erasure, his passing as part of the concretization of the so-called Manifest Destiny. Through his act of sacrifice, he has redeemed himself and reinforced the legitimacy of the Whites. Moreover, his death proves that the two races can never be mixed, and that if assimilation is to take place, it is only through a whitening process that would lead to the very obliteration of the Natives.

The Vanishing American is one of the most vivid examples of a nuanced portrayal of the Native American experience, especially when considering the rather accurate description of corrupt government agencies and their attitudes towards the Indians. However, the film serves an ideological purpose that cannot be overlooked.

Faith in civilization and progress was a determinant background of this way of seeing and portraying the Natives as incapable of adapting to their environment. As the survival of the fittest was the adage of the time, the Indians had to disappear - quite naturally. If there was a minority who did not fit in the all-devouring collective American ideal, it was the Indians. Sioux leader Black Elk expressed his disarray using a similar spatial metaphor of margins and center - "there is no center any longer, and the sacred tree is dead" (Neihardt 1932: 276). The Indian was bound to dwell at the border of a reimagined and internalized frontier and only his shadow resurfaces in America's psyche.

31 The opening sequences of The Vanishing American support the vision of assimilation through a form of social Darwinism, a logic commonly accepted in the early $20^{\text {th }}$ century. Although "mentally inferior", the Indian was often described as "the physical superior of any man on earth except the strong-armed European who cultivated brain along with brawn" (Harrison 1912: 321). George B. Seitz's film opens with an epigraph taken from Herbert Spencer's Principles of Biology (1864), an essay written after reading Charles Darwin's On the Origin of the Species (1859), which states that there has always been "a ceaseless devouring of the weak by the strong", "a survival of the fittest." Here again, keeping in mind René Girard's scapegoat theory, we encounter the attempt to rationalize victimization as an organic part of Evolution.

As we see an impressive image of Monument Valley, an emphasis is made through the title cards on the stillness of Nature, a stage that remains the same whereas "race after race has trod its way from darkness into dark". These Monuments, the "mighty corridor", reflect the frontier as an open passage, a bridge from a race to another. Different tribes are shown as each shot indicates a leap through time. We swiftly move from the little-known Basket Makers to the Clift Dwellers. Native Americans - or their reinvented ancestors - emerge from the shadows, more numerous each time, their "clan spirit" expanding through the centuries. The 
succession through time of these races somehow diminishes the possible inter-relation between them. This little recreation of a yet unknown history could be appealing to the audience in the way it makes up for the blind spots in History to legitimize the coming tale of conquest and survival of the American frontier. Its Biblical tone and vocabulary leaves space for the reimagined Genesis to come. When the Indians finally appear conveniently "no man knows whence" - they strangely assume the pioneers' defining traits, "thirsting for conquest." The High Priest of the Cliff Dwellers can only face the uprising of the stronger Indian race with the prophetic announcement of the coming of an even stronger race. The Spanish explorers in the next scene materialize riding horses and are taken for Gods. We are told that "in every generation, a Nophaie the Warrior dared to do what no other would attempt." This Nophaie tries to steal a white horse - its whiteness strikingly out of place in the desert background - and is shot dead before falling from a cliff. The image is striking: riding the white man's horse will lead the Indian to disintegration. It also foreshadows the events that will occur in the main narrative when Marion gives Nophaie a copy of the New Testament just before he rides away to fight the Great War for the white man. If the first part of the film establishes a rather peaceful and natural integration of the Indians within the confine of the reservation, the nodal point that will mark the character's identity crisis - or mimetic crisis as Girard would have put it - and prompt the sacrificial resolution is the battle scene that takes place on the European front.

Now a sergeant, Nophaie crawls out of a trench and enters the no-man's-land that materially represents the place he occupies in American society. After looking at his New Testament, he finds the courage to brave the enemy's fire and saves Earl Ramsdale (Earl McGregor), Marion's suitor. This suggests that Indians can find a way of filling the gap between races through Christianity, and that their role is to serve the white man's survival. The Vanishing American aims right at the bitterness the Natives experience and directly denounces the injustice they go through. The returning Native American soldiers come back months later to find that their native land has been stolen by Booker (Noah Beery), the corrupt agent of the Indian affairs - the prejudice prompting the final battle scene. "While we fight for them, they steal our homes - our fields! They kill us slow - why not we die like soldiers die?" says one of Nophaie's companions. This time, unlike Griffith's Massacre, the Natives' anger is clearly legitimized. ${ }^{12}$

35 A climactic scene reenacts the opening of the film: Nophaie goes in the desert to perform an ancient ritualistic prayer invoking the Great Spirit. But he quickly stops and realizes that Marion's teachings have prevailed. A close-up unmistakably stresses the importance of the New Testament copy he keeps with him. His Indian faith now seems "a foolish thing." The ritual itself is Christianized as he subsequently turns to God. Nophaie cannot allow himself to abandon his people but his Christian beliefs will not let him seek revenge or nourish hatred. The inner conflict is made visible in a poetical manner. The power of the ancient desert space in all its grandeur is reinvested and condensed into as small an object as a book, shifting from Nature to civilization. The scene judiciously illustrates the Natives' identity crisis and the turmoil of multiculturalism. For Nophaie, as an Indian, resolving his identity is a quest that cannot be dissociated from the struggle to survive - it can only find its resolution in death, the only metaphorical image that allows for racial and cultural hybridization.

Although it is epistemologically problematic to transpose W.E.B. Dubois' concept of "Double Consciousness" to the Natives, the "twoness" and firm delimitation of 
Whiteness and Indianness is indubitable in the "sense of always looking at one's self through the eyes of others" (Dubois 1903: 8). The lifting of the veil, the revelation experienced by Nophaie in his last moment, is here of a false clarity as it only comes through the acceptation of a psychological white dominance. Nophaie's Indianness finally recedes and is more troubling because of the fact that the mediating other is a well-intended and loving woman through whom Nophaie catches a vision of himself which he strives to achieve. Girard's mimesis theory takes a new turn: Nophaie has himself mimicked the white man's attitude towards the Natives; insidiously he has become his own enemy.

Richard Dix's acting is worth commenting upon. Restrained, somehow hesitating, his gestures when making physical contact with either white people or Indians are expressed with reserve, as if he didn't know himself with which peoples he should feel at ease. By the standards of the time, Dix's performance may have reached the limits of refinement, expressing the Hollywood Indian's confused identity. This malaise translates the crisis of representation of the Natives on the big screen. Whether portrayed by true Indians or white people more or less cleverly disguised as Natives, actors' expression were generally grotesque. They "could be grunting, and had an almost perpetual scowl on their faces", they "placed a flat hand above their eyes as though looking far into the distance", as children would when playing cowboys and Indians (Kilpatrick 1999: 34).

\section{A Non-Speaking Image}

In spite of Curtis' efforts to bear witness to the Natives' way of life, the real face of the Indian never appeared on the big screen; nor was his voice heard. The Hollywood Indian substituted himself for the real Natives in the moviegoers' collective imagination and consciousness. Language is an essential parameter to grasp this form of invisibility or forced silence. For the Indians, sound made little change although it revolutionized the film industry, starting with The Jazz Singer in 1927. The writing skills necessary to complement this groundbreaking technical improvement were to be found everywhere from journalists like Ben Hecht to renowned playwrights and novelists. Actors were challenged to make the move to the talkies - some big stars of the silent era disappeared from the screen overnight. The Natives, however, remained silent.

During the silent film era, Indians did not talk much; when synchronized sound made its way into the theaters in the thirties, the distortion took a different magnitude. The Hollywood Indian spoke an alien-sounding language that often was not a genuine Native language, therefore excluding Natives from the audience and increasing their misrepresentation. Their English dialogue was sometimes shot spoken backwards and later printed in reverse so that a new artificial "Indian" language was heard. ${ }^{13}$ As Jacquelyn Kilpatrick states in her seminal work Celluloid Indians, "when language is missing, the instinct is generally to place the voiceless into the margins, which is exactly where most filmic minorities have historically resided" (Kilpatrick 1999: 37). Perhaps the original misfit, the Native Other was doomed to silence from the early days of the cinema industry. To this day, few examples of films directed by non-Native people have tried to balance this situation. Jim Jarmusch's Dead Man (1995) made a point to include genuine and untranslated Makah dialogue, restoring an authentic 
space for Native people to receive and experience the film. Yet this example had to come from an independent and freewheeling director, working outside the production norms of the culture industry.

The origin of this inability of seizing the Other's language can be traced back to Christopher Columbus himself. In The Conquest of America, Tzvetan Todorov presents the first contact between the Natives and the European explorer as the perfect example of a true encounter - albeit a failed one. After all, Columbus' whole enterprise was founded on a language-related misunderstanding, when he translated Arabic miles unto Italian miles. Even the term by which the Natives are designated is strictly a white conception, as Robert F. Berkhofer pointed out in The White Man's Indian (1978). Todorov argues that Columbus' attitude towards Native American languages could only lead to a failure to communicate as his behavior took two complementary forms: "to acknowledge it as a language but to refuse to believe it is different; or to acknowledge its difference but to refuse to admit it is a language" (Todorov 2002: 30). Unexpectedly from a man who was a polyglot, this flawed conception laid the ground for a racist ideology. Todorov expertly establishes that Columbus saw the Natives "not only as equals but also as identical, and this behavior leads to assimilation, the projection of his own values on the others" (Todorov 2002: 42). Their difference and singularity could only be articulated through the notion of inferiority - otherness in itself was denied. Herein lies the origin of the stereotype: for Columbus, all Indians seemed alike in their nudity; at best, they were part of the landscape. As a product of the wilderness, they unsurprisingly become part of the background in Westerns.

\section{The Fear of Becoming an Indian}

41 The twenties were not only the time of a technological upheaval for the Hollywood industry but also the age of a repressed anxiety that would eventually burst with the Great Depression. The fear of miscegenation, but also that of infection, of becoming an Indian, were persistent themes during the decade. Even a writer like Hemingway, who was a product of his times, subconsciously showed the "national anxiety over a changing American racial landscape" (Dudley 2011: 5). His short story Indian Camp, first published in 1924, and re-issued a year later in the collection of short stories entitled In Our Time, reenacts the European settlers' initial journey into foreign Native territory through the crossing of a river. The spatial divide shows how far away the Indian camp remains from civilization; it is a "movement from lightness into curious darkness" (Dudley 2011: 31), which, not unlike the introductory sequence of The Vanishing American, signals a psychological regression. This shows the road towards civilization can be travelled backwards as well. Indian characters have a ghostly presence; they are not given any name, they are passive and do not speak - again, they are barely distinguishable from their surroundings. This representation of uncivilized and unassimilated Natives indicates the emergence of a third major archetype that Berkhofer named the "degraded" or "reservation Indian". This white image seems lifeless and non-dynamic as it is beyond redemption through death or assimilation.

This spatial divide prefigures the racial differentiation Hemingway subtly addresses by the end of his short story. While the object of the journey into the Indian camp was to help a Native woman deliver her baby, one episode reverses the readers' initial expectations. The Indian woman bites one of the characters, Uncle George, unwillingly 
forcing a degree of closeness between races. This time, we discover "the lines that separate white from non-white are forged and - most importantly - they are quite erasable" (Dudley 2011: 29). This demonstrates the very fragility of white Americans' identity and authority, as well as the power the American soil and the Indian camp have over white imagination. In the words of Turner himself, the wilderness has the power to change and master the colonist. "It strips off the garments of civilization" and before long the white man becomes an Indian himself and "shouts the war cry and takes the scalp in orthodox Indian fashion" (Turner 1920: 4).

Another striking example of the mechanism explored above would be King Vidor's Northwest Passage (1940), a work of implicit propaganda used in the wake of the United States' involvement in World War II by the National Education Association to teach children the necessity of engaging in a fight for freedom. Taking place in 1759 in the time of the French and Indian War, the film is a vivid testimony to the historical moment during which it was produced..$^{14}$ Just as $1914-15$ opened the market for a more aggressive feature film production, World War II made necessary "to bolster morale and present the military as a force with a noble history, invincible, and quintessentially American" (Kilpatrick 1999: 19). The climate was indeed comparable to the 1910s and the War raging in Europe probably played a large part in the nationalist perspective the movie displays. But the use of such a film as an educational ideological tool implicitly made the Natives an analogy for the Nazis, thus substituting an enemy image for another. In this context, the Natives could only be depicted as outright antagonists. In Imagined Communities (1983), Benedict Anderson shows that "nation-ness" is but a cultural artefact that commands "profound emotional legitimacy" (4) and establishes boundaries, new frontiers, "beyond which lie other nations" (7). The Natives, and the savage archetype in particular, would then correlate with the enemy abroad, both of them being delineated outside the realm of nationality. 


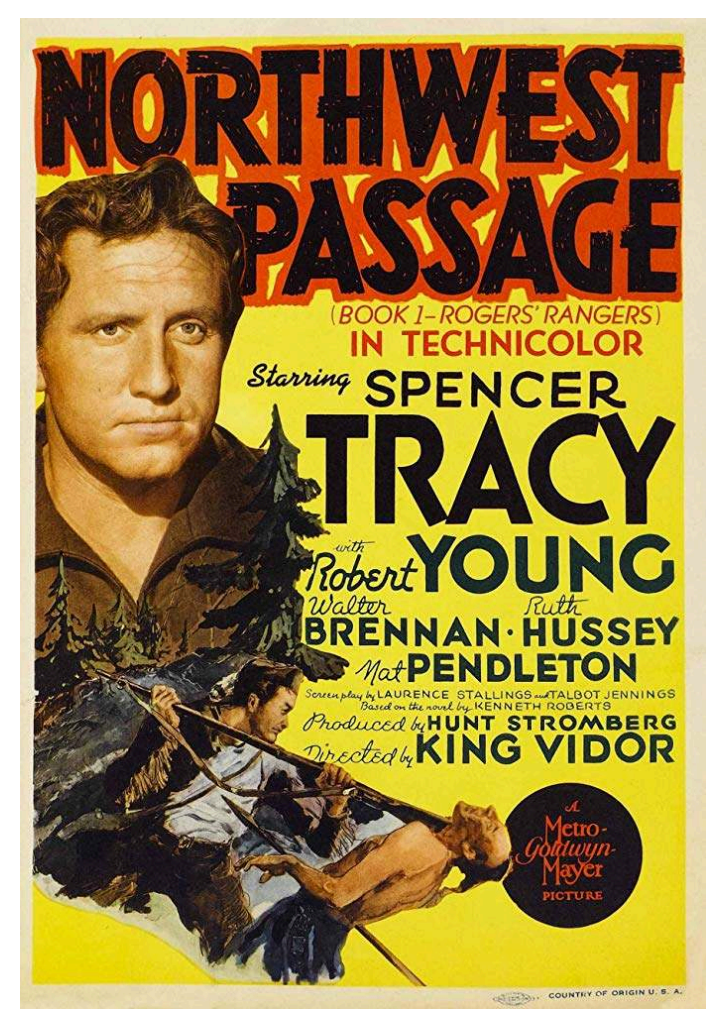

Source: IMDB

Centered on the unlikely relationship between Langdon Towne (Robert Young) and Major Rogers (Spencer Tracy), Northwest Passage is a significant occurrence of the savage Indian stereotype. Langdon wants to be an American artist and his ambition is to paint the Natives "as they really are" because "no one has done that before." In return for joining his rangers, for whom he will use his talent to draw maps, the Major pledges to "show [him] all the Indians [he] can paint." The premises of the story may echo Edward S. Curtis' lifelong aspiration, as Langdon's desire expresses the apparent will to go beyond stereotypes and mythification. But this will not be maintained throughout the narrative, as Major Rogers' influence grows stronger. "The best way of dealing with Indians" might just be, in Rogers' perspective, to roast or destroy them. ${ }^{15}$ The journey from which Langdon goes "rendering them [Indians] on canvas or paper, in oil or watercolor" to "shooting them dead" (Prats 2000: 1) parallels the shift in representation from romanticizing Indians to antagonizing them.

The first Indian we get to see is a submissive drunk, soon followed by a group of docile Mohawks characterized by their cowardice as they refuse to obey Rogers and engage battle - "this is no time for war" says one of them. We do not see the hostile Abenakis until the final battle scene which recalls Griffith's surprise raid on the Indian camp in The Massacre. The incredibly violent scenes of the burning Indian camp leave no space for the Natives to defend themselves or to be shown as human victims. Their presence is mostly conveyed through the rangers' comments about their cruelty and savagery. In a pivotal scene, Rogers addresses his men and introduces Lt. Crofton (Addison Richards) whose brother has been killed two years earlier in an Indian raid in Saint Francis. Crofton delivers a painful speech, describing how the savages "tore [his] brother's arm out of him." The cinematic apparatus allows the ranger to address both 
his fellow men and the audience simultaneously. Facing the camera, the didactic aspect of this moment is impressively efficient. During the final and murderous attack, Crofton loses his mind and "goes blood simple", ${ }^{16}$ scalping an Indian after maiming him with a machete - a phenomenon reminiscent of Turner's description. He eventually vanishes, jumping from a cliff, suggesting that there is no return from this state of savagery. This is an oblique way of blaming the Natives for all acts of exceptional cruelty, and consequently of legitimating the rangers' military exactions. The only possible articulation of an Indian counter-argument to the racism carried through the dialogues of the film manifests through the words spoken by a white woman portrayed by Isabel Jewell, who is soon afterwards brutalized and thrown to the ground by Rogers. "She's been living here [in the Indian camp]", we are told, "she's worse than any of those reds."

\section{Maintaining the National Feeling}

47 The reappearance of violence and the hardening of the savage Indian stereotype illustrate how the Second World War put an end to the Depression by making the country enter a war economy that vividly required the focalization on a sustainable enemy image. The schizophrenic aspect of this mechanism would eventually erupt during the sixties, the anti-military philosophy of the countercultures merging with a renewed interest in alternative lifestyles, including that of the Natives, in a sometimes idealized fashion - they were often described as primitive communists or environmentalists - that marked a return to the primitivism of earlier times. Less control on the part of the culture industry - the Motion Picture Production Code was abandoned by 1968 - meant that for a short time America's relationship with the Natives could be reconfigured. ${ }^{17}$

By the end of the decade and early seventies, many Westerns challenged the main tropes of the genre. In an era of growing political skepticism, defined by uncertainty and a series of brutal changes, a need for more realism, flawed and conflicted protagonists emerged. As a Revisionist Western, Jeremiah Johnson (Sydney Pollack, 1972) is emblematic of this renegotiation of racial space. It portrays nuanced and psychologically complex Native characters - not stereotypes -, as well as the reciprocity, for better and for worse, of relationships between Whites and Indians. It is also a subtle and critical reading of the Vietnam War. Seeking isolation from society in the wilderness because of the Mexican War (1846-1848) - a conflict denounced by the likes of Emerson and Thoreau, reflecting the U.S. involvement in Indochina in the 1960s -, Johnson (Robert Redford) ends up recomposing his life with a young boy whose family has been savagely killed by Blackfoot Indians and the daughter of the Chief of another tribe. Beyond language and cultural impairment, the three are able to live together peacefully. Although the protagonist ultimately loses everything because he has knowingly crossed a sacred Crow burial ground and retaliates with equal violence, the last sequence of the film seeks resolution through appeasement: Johnson, facing a Crow Indian in the distance, sees the man raise his hand with open palm, in sign of peace. Instead of drawing his rifle, Johnson raises his hand in return, breaking the cycle of violence (Figure 6). He realizes the man he is facing is his fellowman and a true encounter takes place: for the first time in cinema history, the Natives could be met for who they were - without sentimentality, guilt, nor prejudice. Far from the traditional 
Western aesthetic, cinematic space is shared symmetrically in that scene, establishing the equality of the races, albeit with a respectful distance.

Figure 6. Stills from Jeremiah Johnson (1972), by Sidney Pollack

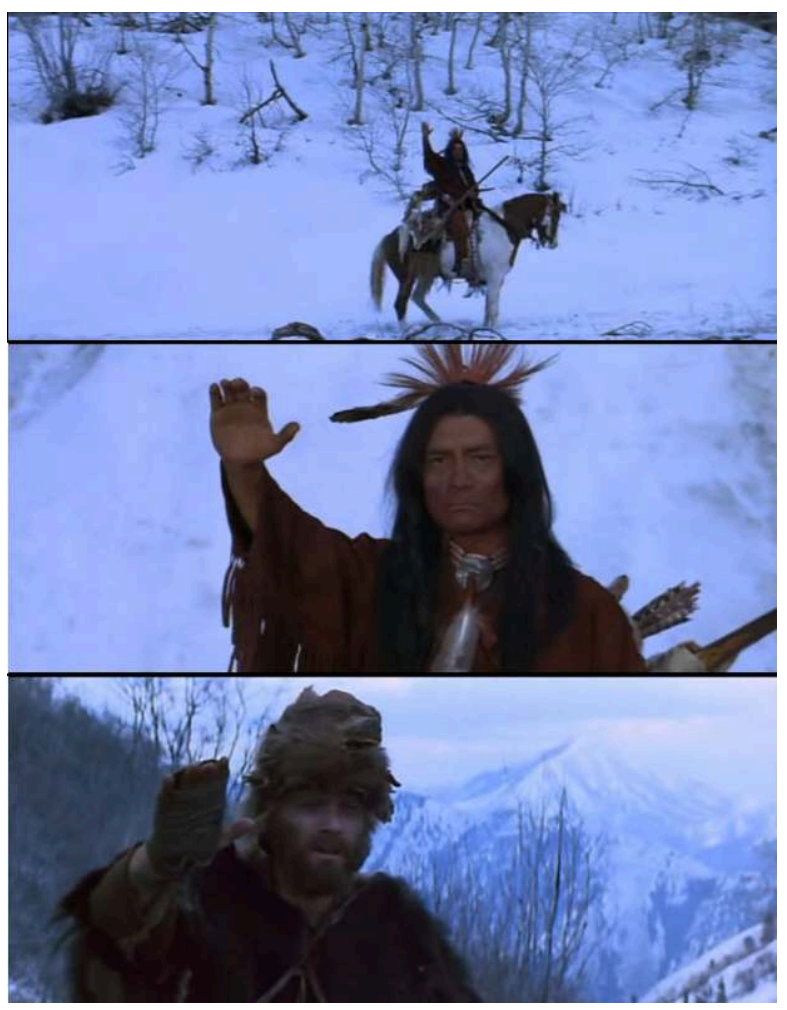

Considering the monolithic aspect of the Indian stereotype in American culture, it might be challenging not to see the other as a static object. Hollywood purposely pictured the Indians that way, at least for narrative convenience. It was necessary for mainstream society to freeze this image and representation of the Natives in a certain light to keep up with social and technological progresses in the early $20^{\text {th }}$ century and make sense of the Nation's destiny. René Girard's critical stances lead us to question the authenticity of a national desire that may have grown out of control, but definitely served the United States' growing involvement in the international stage.

Griffith's The Massacre or Seitz's The Vanishing American are perfect examples of white backlash. The unwillingness of the directors and producers to let the story converge to its organic ending - a romance between races in the latter case - exposes a psychological resistance that has not yet been overcome. It also depicts a movement from the natural world to a cultural and political world where Darwinian ideology served as a mean of rationalization of the violence exerted upon the Natives. But what the biology of the Hollywood Indian image reveals is a mimetic evolution that is more complex than the slower and normal Darwinian process, reimagined in the opening sequences of The Vanishing American where the tribes succeeded over time without interrelating with each other. To survive through adaptation and mimesis and to ultimately transform and replace the original American through the construction of an enemy image represents a technological and cultural leap that is far from natural. It is the gesture by which the Nation asserts itself and shapes a perennial mainstream society, mastering its collective destiny. Through the Western genre and the Hollywood 
Indian, Americans and the culture industry have reimagined and mythicized History, thereby conferring to this recreation the status of unchallenged reality.

The vanishing Indian trope that radiates through the dominant discourse, peaking in the early $20^{\text {th }}$ century, is a white American construction that laid the ground for the reinforcement of the Indian enemy image and erasure of the good Indian stereotype. Although the demographic growth that started in the 1930s proved otherwise, the Western culture and Indian stereotypes steeped deep in the American consciousness to the point of obliteration of Native identity.

Native ethnologist Francis La Flesche recalls in his memoir The Middle Five: Indian Boys at School (1978) how western education and the "House of Teaching" aimed at erasing Indianness altogether. If Indian plays remain so ambivalent, it is because they reenact the Westerns clichés and Girard's process of imitation, simultaneously constructing an image that stands for and against the Indians and destructing Native identity (see Deloria 1999). Thomas King, a Native rights activist of Cherokee descent, remembers in his book The Inconvenient Indian (2012) how he and his brother would dress and play cowboys and Indians, always choosing the cowboy part. "I don't remember anyone who wanted to be an Indian", he writes (King 2012: 21). This shows how the culture industry impacted the mind of Native Americans and how it can deprive somebody of his own sense of identity. Living in "a world in which you were either a cowboy or an Indian" (King 2012: 23) did not leave much room to trigger a powerful and genuine desire to claim your heritage. How can Native people reclaim their Indianness and what lies in the shadows of the enemy image - an authentic Americanness? Is it possible for Native Americans to subvert this history and fantasies of conquest and assimilation to forge a counter-narrative where the Natives' civilization was actually destroyed by the white savage? Or, as Luther Standing Bear wrote, where "the man from Europe is still a foreigner and an alien" (Standing Bear 1978), and the Indian the rightful inhabitant of the American territory - because it is and has always been about the land?

The true revelation offered by this focus on this enemy image is that the assimilation of the good Indian stereotype and the disintegration of real Native identity attest to the subjectivity of the stories told through the cinematic medium: Western films relate here only the persecutor's perspective. The Vanishing American suggests that the victimization and sacrifice through the enemy image that was projected on the Natives and self-internalized by both the Whites and the Indians can lead to a possible neutral point of conciliation. The displacement and the distance necessary to embrace the point of view of the victim point to a potential way out of this enemy image construction - but it would imply purging History of its misrepresentation to meet the Natives and face what they have to say. At the other extreme of the enemy image production lies an even more challenging issue: the possibility that the national feeling may not be shared in an all-inclusive society. 


\section{BIBLIOGRAPHY}

Adorno, Theodor W., and Max Horkeimer. Dialectic of Enlightenment. Stanford: Stanford UP, 2002 (1947).

Anderson, Benedict. Imagined Communities: Reflections on the Origin and Spread of Nationalism. London and New York: Verso, 2006 (1983).

Berkhofer, Jr., Robert F. The White Man's Indian: Images of the American Indian from Columbus to the Present. New York: Alfred A. Knopf, 1978.

Bush, Stephen W. "Moving Pictures Absurdities." Moving Picture World 9.10 (September 16, 1911): 773. https://archive.org/details/moviwor09chal/page/n789/mode/2up

Bush, Stephen W. "In the Land of the Head-Hunters." Moving Picture World 22.12 (December 19, 1914): 1685. https://archive.org/details/movingpicturewor22newy/page/1684/mode/2up

Cooper, James Fenimore. The Last of the Mohicans: A Narrative of 1757. Philadelphia: H.C. Carey \& I. Lea, 1826.

Cushman, Philip. Constructing the Self, Constructing America: A Cultural History of Psychotherapy. Cambridge: Da Capo Press, 1996.

Darwin, Charles. On the Origin of Species by Means of Natural Selection, or the Preservation of Favoured Races in the Struggle for Life. London: John Murray, 1859.

Delaney, Michelle. Buffalo Bill's Wild West Warriors: A Photographic History by Gertrude Käsebier. Smithsonian National Museum of American History, 2007.

Deloria, Philip J. Playing Indians. New Haven: Yale UP, 1999.

Dippie, Brian W. The Vanishing American: White Attitudes \& U.S. Indian Policy. Lawrence: UP of Kansas, 1982.

Dubois, W.E.B. The Souls of Black Folk: Essays and Sketches. Chicago: A.C. McClurg \& Co., 1903.

Dudley, Marc Kevin. Hemingway, Race, and Art: Bloodlines and the Color Line. The Kent State University Press, 2012.

Curtis, Edward S. The North American Indian: The Complete Portfolios. Cologne: Taschen, 1997.

Evans, Brad, and Aaron Glass. Return to the Land of the Head Hunters: Edward S. Curtis, the Kwakwaka'wakw, and the Making of Modern Cinema. Seattle: University of Washington Press, 2014.

Freud, Sigmund. Totem and Taboo: Resemblances Between the Mental Lives of Savages and Neurotics. Boston: Beacon Press, 1913.

Girard, René. Violence and the Sacred. Baltimore: Johns Hopkins UP, 1977 (1972).

Girard, René. The Scapegoat. Baltimore: Johns Hopkins UP, 1986 (1982).

Girard, René. I See Satan Fall Like Lightning. Maryknoll: Orbis Books, 2001 (1999).

Girard, René, with Pierpaolo Antonello \& Joao Cezar de Castro Rocha. Evolution and Conversion: Dialogues on the Origins of Culture. New York: Continuum International Publishing Group, 2008. Grey, Zane. The Vanishing American. New York: HarperCollins, 1991.

Hammett, Dashiell. Red Harvest. New York: Alfred A. Knopf, 1929. 
Harrison, Louis Reeves. “The ‘Bison 101' Headliners.” Moving Picture World 12.4 (April 27, 1912): 320-2. https://archive.org/details/movingpicturewor12newy/

Hearne, Joanna. “The Cross-Heart People: Race and Inheritance in the Silent Western." Journal of Popular Film and Television 30.4 (Winter 2003): 181-96. DOI: 10.1080/01956050309602855

Hemingway, Ernest. In Our Time. New York: Boni \& Liveright, 1925.

Holm, Bill and George Irving Quimby. Edward S. Curtis in the Land of the War Canoes: A Pioneer Cinematographer in the Pacific Northwest. Seattle: U. of Washington P., 1980.

Jay, Gregory S. “'White Man's Book No Good': D. W. Griffith and the American Indian.” Cinema Journal 39.4 (Summer 2000): 3-26. https://www.jstor.org/stable/1225883

Jentz, Paul. Seven Myths of Native American History. Indianapolis: Hackett Publishing Company, 2018.

Kilpatrick, Jacquelyn. Celluloid Indians, Native Americans and Film. Lincoln: University of Nebraska Press, 1999.

King, Thomas. The Inconvenient Indian: A Curious Account of Native People in North America.

Minneapolis: U. of Minnesota P., 2012.

Kracauer, Siegfried. From Caligari to Hitler: A Psychological History of the German Film. Princeton: Princeton UP, 1966 (1947).

La Flesche, Francis. The Middle Five: Indian Schoolboys of the Omaha Tribe. Lincoln and London: U. of Nebraska P., 1978.

Lawrence, D.H. Mornings in Mexico and Other Essays. Cambridge: Cambridge UP, 2009 (1927).

Lyman, Christopher M. The Vanishing Race and Other Illusions: Photographs of Indians by Edward S. Curtis. New York: Pantheon Books, in association with the Smithsonian Institution Press, 1982.

McNenly, Linda Scarangella. Native Performers in Wild West Shows: From Buffalo Bill to Euro Disney. Norman: U. of Oklahoma P., 2012.

Neihardt, John G. Black Elk Speaks. New York: William Morrow \& Company, 1932.

Österberg, Bertil O. Colonial America on Film and Television: A Filmography. Jefferson, North Carolina, and London: McFarland \& Company, 2001.

Prats, Armando José. Invisible Natives: Myth and Identity in the American Western. Ithaca and London: Cornell UP, 2002.

Quimby, George I. "The Mystery of the First Documentary Film.” The Pacific Northwest Quarterly 81.2, University of Washington (April 1990): 50-53. https://www.jstor.org/stable/40491115

Standing Bear, Luther. Land of the Spotted Eagle. Lincoln and London: U. of Nebraska P., 1978 (1933).

Slotkin, Richard. Regeneration Through Violence: The Mythology of the American Frontier, 1600-1860. Middletown, Conn: Wesleyan UP, 1973.

Spencer, Herbert. Principles of Biology. London: Williams and Norgate, 1864.

Stam, Robert and Ella Shohat. Unthinking Eurocentrism: Multiculturalism and the Media. New York: Routledge, 1994.

Todorov, Tzvetan. The Conquest of America: The Question of the Other. Trans. Anthony Pagden.

Norman: U. of Oklahoma P., 2002 (1982). 
Tompkins, Jane. West of Everything: The Inner Life of Westerns. New York: Oxford UP, 1992.

Turner, Frederick Jackson. The Frontier in American History. New York: Holt, 1921.

Wagenknecht, Edward and Anthony Slide. The Films of D. W. Griffith. New York:

Crown, 1975.

Widkin, Robert W. Adorno on Popular Culture. New York: Routledge, 2003.

\section{Films (in chronological order)}

Sioux Ghost Dance (William K. L. Dickson, William Heise, 1894).

Parade of Buffalo Bill's Wild West Show (William Heise, 1898).

The Red Man and the Child (D.W. Griffith, 1908).

The Indian Runner's Romance (D.W. Griffith, 1909).

The Red Man's View (D.W. Griffith, 1909).

White Fawn's Devotion: A Play Acted by a Tribe of Red Indians in America (James Young Deer, 1910).

A Pueblo Legend (D.W. Griffith, 1912).

The Massacre (D.W. Griffith, 1912).

The Indian Wars Refought (Theodore Wharton, 1914).

In the Land of the Head Hunters (Edward S. Curtis, 1914).

The Birth of a Nation (D.W. Griffith, 1915).

Nanook of the North (Robert Flaherty, 1922).

The Vanishing American (George B. Seitz, 1925).

Moana (Robert Flaherty, 1926).

Northwest Passage (King Vidor, 1940).

Northward Ho! (Harry Loud, 1940).

Cheyenne Autumn (John Ford, 1964).

Jeremiah Johnson (Sydney Pollack, 1972).

Dances with Wolves (Kevin Costner, 1990).

Twin Peaks (Mark Frost, David Lynch, 1990-91, 2017).

Dead Man (Jim Jarmusch, 1995).

\section{Sculpture}

Fraser, James Earle (American, 1876-1953). End of the Trail, 1918 (cast 1918). Bronze; 33 x 26 x 8 $3 / 4$ in. $(83.8$ x 66 × $22.2 \mathrm{~cm})$. The Metropolitan Museum of Art, Purchase, Friends of the American Wing Fund, Mr. and Mrs. S. Parker Gilbert Gift, Morris K. Jesup and 2004 Benefit Funds, 2010 (2010.73). https://www.metmuseum.org/art/collection/search/20461 


\section{From the U.S. Library of Congress}

Edison, Thomas A. Inc, Paper Print Collection, and Niver. Parade of Buffalo Bill's Wild West show. No. 2. United States: Edison Manufacturing Co, 1898. Video. https://www.loc.gov/item/2015600173

Heise, William, Camera, Inc Thomas A. Edison, and Hendricks. Sioux Ghost Dance. [United States: Edison Manufacturing Co, 1894] Video. https://www.loc.gov/item/00694139

Käsebier, Gertrude, photographer. Chief Iron Tail, a Sioux Indian from Buffalo Bill's Wild West Show. Photograph. https://www.loc.gov/item/2006679560

Sarony, Napoleon, Copyright Claimant, and Merritt Van Wagner. Buffalo Bill's Wild West Show, -1891. c1886-c1891. Photograph. https://www.loc.gov/item/2004665295

\section{NOTES}

1. Critics used to refer to Westerns through the use of various labels - a western romance or a western melodrama for instance - and the name itself first appeared in a July 1912 article printed in Motion Picture World. It proves that those films were not a coherent production genre at the time and that the Western as a genre was not defined as such until the 1930s.

2. The question remains open: were Native performers aware of the impact of this particular brand on entertainment on the audience or did they, as Kilpatrick suggests, underestimate the power of show business? Many actually praised Cody for his financial and legal support. However, the Office of Indian Affairs (O.I.A.), renamed Bureau of Indian Affairs in 1947, Indian Schools, and paternalist reformers at large, tried to prevent Native Americans from joining Buffalo Bill's Wild West Show to protect them from exploitation and to ensure the ongoing process of assimilation. See Jentz (2018: 123), and McNenly (2012: 39).

3. For photographs documenting the life and activities of Native American performers in Buffalo Bill's Wild West Show see Sarony (1891) at The Library of Congress. See also Delaney (2007). Kasebier's portrait of Chief Iron Tail best exemplifies her desire to photograph a "real raw Indian, the kind I used to see when I was a child" (Delaney 2007: 16).

4. One could also argue that there is no narrative structure, no story told, in Edison's Kinetoscope features.

5. See Edward S. Curtis' introduction to the first volume of The North American Indian (1907).

6. See Wagenknecht \& Slide (1975). It is generally accepted, although debatable, that the treatment of American Indians in the Biograph productions "was almost consistently sympathetic" (Wagenknecht \& Slide 1975: 13).

7. The plot of The Red Man's View somehow anticipates John Ford's Cheyenne Autumn (1964). James Earle Fraser's bronze sculpture End of the Trail (1918) is reminiscent of the motif of the Indian race being pushed to the edge of the Pacific.

8. First released in 1914 under the title In the Land of the Head Hunters and shot in the region of British Columbia with Native people only, the film was rediscovered in the 1970's and re-released as In the Land of the War Canoes. The Library of Congress now preserves it in the U.S. National Film Registry. It notoriously influenced Robert Flaherty's groundbreaking Nanook of the North (1922).

9. The film is arguably the first feature-length documentary, a term that would only appear in 1926 when Scottish filmmaker John Grierson reviewed Robert Flaherty's Moana (1925).

10. See Bill Holm and George Irving Quimby (1980). With the agreement of their Kwakiutl consultants, Holm and Quimby changed the title to In the Land of the War Canoes because they "noticed that outstanding portions of the film show the magnificent war canoes in all their glory" (Holm and Quimby 1980: 15). 
11. In a sense, the Revisionist Western may be seen as a counter-action to soothe potential violence incurred through the rise of the Red Power movement in the 60s-70s.

12. In 1919 U.S. President Woodrow Wilson granted citizenship to Native Americans who served in World War I, a few years before President Calvin Coolidge signed the Indian Citizenship Act in 1924.

13. Oddly enough, this process was used by David Lynch and Mark Frost in the making of the cult television show Twin Peaks (1990-1991, 2017) when the characters entered the Black Lodge, a mythological place referenced in the stories of the Nez Perce tribe of northeastern Washington that embodies the psychological unconscious and its perils. The series is filled with allusions to Native traditions, which show the infiltration of Indian consciousness in popular culture and its very location in the underground of American consciousness. The working title of the show, Northwest Passage, was also directly linked to the Natives but dropped due to its proximity with another film with the same title.

14. The film's genesis involved a dozen writers and three directors, including W.S. Van Dyke, and Vidor went on location without a finished script. The behind-the-scenes featurette Northward Ho! (Harry Loud, 1940) documents the "towering task" of recreating "one of the most heroic episodes" in American history, comparing it to the staging of the Storming of the Bastille in a previous release. It was the most expensive movie MGM had made at the time and the shooting took on epic proportions in the wilderness of Idaho as Vidor reportedly worked his crew under hard conditions. According to Österberg (2001: 196) "more than 300 local Natives from the Nez Percé reservation were hired" and it is said "they claimed a \$10-per-day fee for acting, but that they accepted a \$5-per-day fee from Vidor (on advice of Tracy) because he said they were only a cast of half-breeds."

15. "The French will find at Saint Francis nothing but roast Indians," comments Rogers right after the battle scene. He later feels honored "to report the Abenakis are destroyed."

16. From Dashiell Hammett's Red Harvest (1929), the expression "going blood-simple like the Natives" aptly exemplifies the fear of a violent psychological regression. It also gave its name to Joel and Ethan Coen's first feature-length film, Blood Simple (1984).

17. Fraser's End of the Trail Indian became the emblem of Native veterans; the original meaning of the work was somehow reinvented by the Natives themselves as a symbol of resilience and strength.

\section{ABSTRACTS}

This paper intends to demonstrate that the misrepresentation of Native Americans in cinema furthers the logic of differentiation at play in popular culture, focalizing on an irreconcilable enemy image upon which the American self is constructed. The Indian looking glass magnifies America's lack of self-knowledge. Following Frederic Jackson Turner's theory of the frontier and the mythologizing of the West at the turn of the $20^{\text {th }}$ century, the Hollywood industry recycled the dual stereotype of the noble Indian and the bloodthirsty savage. This dichotomy deployed through American cinema and literature fits the evolving curve that defines the limits of a cohesive norm and the dominant vision of what the country is, of what it means to be American. As powerful social agents, movies from the period helped shape the way America thought about Native Americans and contributed to a rewriting of History, summoning those fantasized images manufactured by James Fenimore Cooper's Leatherstocking Tales, dime novels, the paintings of 
Frederic Remington, Buffalo Bill's Wild West Show, or Thomas Edison's Kinetoscope. I argue that the disappearance of the positive representation of Indians in the 1910s is part of a wider process of assimilation that legitimizes and reinforces the position of white mainstream society. More specifically, this essay investigates the process through which the Hollywood Indian became a necessary ideological tool supporting the All American Hero and the war effort in both World Wars. King Vidor's Northwest Passage (1940), a work of implicit propaganda used by the National Education Association, makes the Natives an analogy for the Nazis, thus substituting an enemy image for another. George B. Seitz's The Vanishing American (1925) is also an emblematic example of the use of a dissolving enemy image. As a biased Darwinism inflected the collective consciousness of what was then thought to be their forthcoming extinction, Native Americans had to merge into the conforming frame of the master race, most effectively through the agency of the Office of Indian Affairs and within Indian boarding schools. The Vanishing American culminates with its main character's demise: Nophaie's sacrifice proves the two races can never be mixed, and that if assimilation is to take place, it is only through a whitening process that would lead to the obliteration of the Natives. When Nophaie dies, the moment of his passing is described through a skin color change, his face turning white. While the end of the twenties marked the arrival of synchronized-sound cinema, the Natives lingered "voiceless into the margins", as a silent mirror image that could not speak, epitomizing what the American self was not (Kilpatrick 1999). To this day, white imagination remains unable to articulate the other's language and to see beyond these immutable images.

Cet article envisage la représentation des Indiens, irréconciliable image de l'ennemi à partir de laquelle s'est construite l'identité américaine, comme symptomatique de la logique de la différenciation en jeu dans la culture populaire. La figure de l'Indien est le prisme révélateur du manque de connaissance de soi dont souffre l'Amérique. Suivant la théorie de la Frontière définie par Frederick Jackson Turner et de la mythification de l'Ouest au tournant du siècle, l'industrie hollywoodienne réactualisa le double stéréotype du noble indien et du sauvage assoiffé de sang. Cette dichotomie, déployée au travers du cinéma et de la littérature américaine correspond au tracé aux contours variables qui définit les limites d'une norme cohésive, la vision du pays, et ce que signifie être américain. Les films de cette époque ont altéré la façon dont l'Amérique percevait les Amérindiens et participèrent à une réécriture de l'Histoire, invoquant ces images fantasmatiques popularisées par le cycle Bas-de-Cuir de James Fenimore Cooper, les peintures de Frederic Remington, le Wild West Show de Buffalo Bill, ou le Kinétoscope de Thomas Edison. La disparition d'une représentation positive des Indiens au cours des années 1910 fait partie d'un processus d'assimilation qui légitime et renforce la position de la société blanche dominante. En outre, nous examinerons le processus au cours duquel l'Indien d'Hollywood devint un outil idéologique crucial pour soutenir le héros américain et l'effort de guerre durant les deux guerres mondiales. Northwest Passage (King Vidor, 1940), en tant qu'œuvre de propagande implicite utilisée par la National Education Association, fait ainsi des Indiens un péril analogue aux nazis, substituant une image de l'ennemi à une autre. The Vanishing American (George B. Seitz, 1925) joue un rôle politique semblable. Un darwinisme obscurci infléchit la vision collective de ce qui était alors perçu comme l'extinction imminente des Amérindiens, les poussant à se fondre et à s'évanouir au sein de la race dominante au travers des dispositifs mis en place par le Bureau des affaires indiennes et les écoles indiennes. Le dénouement de The Vanishing American met ainsi en scène la mort de son personnage principal, l'indien Nophaie, dont le sacrifice prouve que les deux races ne pourront jamais se mélanger, et que si une assimilation doit avoir lieu, ce n'est qu'en devenant blanc, conduisant à l'effacement même des Natifs. Sa mort est ainsi traduite par le changement de la couleur de sa peau, son visage devenant blanc. Alors que la fin des années 1920 marquait l'arrivée du son synchronisée au cinéma, les Amérindiens demeurèrent «sans voix, confinés à la marge ", image miroir silencieuse qui ne pouvait parler, emblème de ce que 
l'américain n'était justement pas (Kilpatrick 1999). À ce jour, l'imagination blanche reste incapable de saisir le langage de cet autre et de voir au-delà de ces images immuables.

\section{INDEX}

Mots-clés: Amérindiens, Indien d'Hollywood, noble indien, sauvage, altérité, Autre, stéréotypes, Soi, frontière, Ouest sauvage, Western, industrie culturelle, assimilation, miscégénation, Curtis Edward S., Vidor King, Griffith D.W., Girard René

Keywords: Native American, Hollywood Indian, noble Indian, savage, Other, stereotypes, Self, Frontier, Wild West, Western, culture industry, misrepresentation, assimilation, miscegenation, Curtis Edward S., Vidor King, Griffith D.W., Girard René

\section{AUTHOR}

\section{MARTIN BERNY}

Martin Berny is a Doctoral student at Université Paris-Est (LISAA - Littératures SAvoirs et Arts, laboratoire de l'École Doctorale Cultures et Sociétés), and Lecturer at Université Paris 8. His PhD is provisionally entitled 'Misfit Blues : Les misfits dans le cinéma et la littérature américaine' (Misfit blues : Misfits in American cinema and literature). Contact: martinberny44[at]outlook.fr 